\title{
Changes in the relative abundance of mRNA transcripts for insulin-like growth factor (IGF-I and IGF-II) ligands and their receptors (IGF-IR/IGF-IIR) in preimplantation bovine embryos derived from different in vitro systems
}

\author{
M. A. Yaseen, C. Wrenzycki, D. Herrmann, J. W. Carnwath \\ and H. Niemann* \\ Department of Biotechnology, Institut für Tierzucht und Tierverhalten, Mariensee, \\ 31535 Neustadt, Germany
}

\begin{abstract}
The aim of this study was to determine the relative abundance of mRNAs for the insulin-like growth factor I (IGF-I) and IGF-II ligands, and for the IGF receptors (IGF-IR and IGF-IIR) in in vitro preimplantation bovine embryos from the oocyte to the hatched blastocyst stage using two different culture systems: TCM-199 supplemented with oestrous cow serum, or synthetic oviduct fluid supplemented with polyvinyl alcohol. Development to the two- to four-cell stage and blastocyst stage was significantly higher $(P \leqslant 0.05)$ in embryos cultured in TCM supplemented with oestrous cow serum than in those cultured in synthetic oviduct fluid supplemented with polyvinyl alcohol (61 and $25 \%$ versus 55 and $17 \%$, respectively). A semi-quantitative RT-PCR assay did not detect IGF-I transcripts at any stage of preimplantation bovine development, including the hatched blastocyst stage. In both culture systems, IGF-IR, IGF-II and IGF-IIR were expressed throughout preimplantation development up to the hatched blastocyst stage in a varying
\end{abstract}

\section{Introduction}

Insulin and insulin-like growth factors (IGFs) are a group of structurally related polypeptides that regulate the growth of many types of mammalian cells. The growth-promoting activity of these polypeptides is mediated by binding to receptors on the cell membrane. Receptors with primary binding specificity for these polypeptides have been identified (Baxter, 1988). IGF transport and function are modulated by interactions with at least six insulin-like growth factor binding proteins (IGFBPs), which are present in many extracellular fluids and in early embryos (Heyner et al., 1993; Kaye and Harvey 1995; Winger et al., 1997; Luciano et al., 2000). IGFs enhance cell proliferation, mitogenesis and steroid hormone activity (Adashi et al., 1985; Kamada et al., 1992).

Several lines of evidence indicate that the polypeptide

*Correspondence

Email: niemann@tzv.fal.de pattern. The expression patterns of IGF-IR, IGF-II and IGFIIR in embryos generated in the two culture systems were not significantly different, except at the expanded blastocyst stage, at which significantly higher amounts of IGF-IIR were observed in the TCM system than in the synthetic oviduct fluid system. These results indicate that transcripts of IGF-IR and IGF-IIR follow the standard pattern in which maternal stores of mRNA in the oocyte are slowly depleted up to the 16-cell stage and then re-established at the onset of embryonic expression of these genes. The lack of detectable IGF-I transcripts in the bovine embryo indicates a predominantly paracrine mode of action. The bovine embryo is capable of producing IGF-II, IGF-IIR and IGF-IR in large amounts, particularly after hatching, which may be important for the formation of the filamentous conceptus. Results indicate an autocrine mechanism for IGF-II and modulation of IGF family expression by culture conditions. growth factors of the IGF family have an important role in early development. Growth factors have been identified in follicular fluid (Hammond et al., 1988) and in the female reproductive tract (Buhi et al., 1997). The addition of exogenous IGF-I or -II to the culture medium results in improved bovine oocyte maturation and embryonic development (Herrler et al., 1992; Kaye et al., 1992; Matsui et al., 1995; Palma et al., 1997, Pawshe et al., 1998; Mihalik et al., 2000). Expression of mRNA transcripts for the IGF family has been detected in embryos of a variety of species. Although IGF-IR, IGF-II and IGF-IIR are expressed throughout preimplantation development up to the blastocyst stage, expression of IGF-I ligand by preimplantation embryos has also been reported. For example, IGF-I expression was detected in bovine and ovine embryos produced in vitro (Schultz et al., 1992; Watson et al., 1992, 1994; Yoshida et al., 1998), but was not observed in embryos from water buffalo (Daliri et al., 1999), mice (Rappolee et al., 1992), rats (Zhang et al., 1994) and humans (Lighten et al., 1997a). 
Niemann and Wrenzycki (2000) reported that transcription of several developmentally important genes in preimplantation embryos is affected by the in vitro environment, possibly leading to perturbation of differentiation and organogenesis, and 'large offspring syndrome'. The amounts of various transcripts were correlated with the presence or absence of the respective protein in the culture medium. Bovine embryos responded to changes in their environment very early on in development by modifying the synthesis of specific mRNAs (Wrenzycki et al., 1999). mRNA expression of IGFs, their receptors and IGFBPs during bovine preimplantation development varies qualitatively (Schultz et al., 1992; Watson et al., 1992; Winger et al., 1997; Yoshida et al., 1998; Lonergan et al., 2000) and the changes in the abundance of IGF-I mRNA and IGF-IR in relation to culture medium composition have not yet been investigated.

The aim of this study was to determine the relative abundance of mRNAs for the IGF-I and IGF-II ligands and their receptors (IGF-IR and IGF-IIR) in preimplantation bovine development up to the hatched blastocyst stage using two different in vitro culture systems: TCM-199 with oestrous cow serum, or synthetic oviduct fluid with polyvinyl alcohol. These two contrasting culture systems (complex and undefined versus simple and defined) were used to determine effects on mRNA expression originating from the in vitro production process. The study also aimed to clarify whether in vitro produced bovine embryos express IGF-I ligand during preimplantation development.

\section{Materials and Methods}

\section{In vitro production of embryos}

Bovine oocytes and embryos were produced using standard protocols for in vitro maturation, fertilization and culture (Eckert and Niemann, 1995; Wrenzycki et al., 1996, 1999). Briefly, bovine ovaries obtained from a local abattoir were transported in PBS (No. D5773; Sigma, St Louis, MO) at $25-30^{\circ} \mathrm{C}$ to the laboratory, where they were washed twice in fresh PBS. Ovaries were sliced with razor blades in PBS containing 2 iu heparin $\mathrm{I}^{-1}$ (Serva, Heidelberg) and 2.0\% NBCS (newborn calf serum; Boehringer Mannheim), or $0.1 \%(\mathrm{w} / \mathrm{v})$ polyvinyl alcohol (No. P8136, Sigma), to release cumulus-oocyte complexes (COCs) (Eckert and Niemann, 1995). The resulting suspension was passed through a filter to isolate COCs. Category I COCs (with a homogeneous evenly granulated cytoplasm with at least three layers of compact cumulus cells) and category II COCs (with fewer than three layers of cumulus cells or partially denuded, but also with a homogeneous evenly granulated cytoplasm; Pavlok et al., 1992) were pooled in TCM-air (TCM-199 containing L-glutamine and $25 \mathrm{mmol}$ Hepes $\mathrm{I}^{-1}$ (Sigma) supplemented with $22 \mu \mathrm{g}$ pyruvate $\mathrm{ml}^{-1}$, $350 \mu \mathrm{g} \mathrm{NaHCO} \mathrm{ml}^{-1}, 50 \mu \mathrm{g}$ gentamicin $\mathrm{ml}^{-1}$ and $1 \mathrm{mg}$ BSA $\mathrm{ml}^{-1}$ (fraction $\mathrm{V}$ ) or polyvinyl alcohol). TCM-199 containing L-glutamine and $25 \mathrm{mmol}$ Hepes $\mathrm{I}^{-1}$ served as the basic medium for in vitro maturation. TCM-199 (1 ml) was supplemented with $22.0 \mu \mathrm{g}$ pyruvate $\mathrm{I}^{-1}, 2.2 \mathrm{mg}$ $\mathrm{NaHCO}_{3} \mathrm{I}^{-1}$ and $50.0 \mu \mathrm{g}$ gentamicin ${ }^{-1}$. For oocyte maturation, the same medium was supplemented with 10 iu eCG $\mathrm{ml}$ (Intervet Tönisvorst), 5 iu hCG $\mathrm{ml}^{-1}$ (Intervet Tönisvorst) and either $10.0 \%$ heat-inactivated (30 min at $56^{\circ} \mathrm{C}$ ) oestrous cow serum (collected on day 1 of standing oestrus) or $0.1 \%$ polyvinyl alcohol. Fresh COCs were washed three times in TCM-199 supplemented with $10.0 \%$ oestrous cow serum or $0.1 \%$ polyvinyl alcohol, and then divided into groups of 20-25, transferred into $100 \mu \mathrm{l}$ maturation drops under silicone oil and cultured in a humidified atmosphere of $5 \% \mathrm{CO}_{2}$ in air at $39^{\circ} \mathrm{C}$ for $24 \mathrm{~h}$. After in vitro maturation, COCs were rinsed in fertilization medium (fert-Tyrode's albumin lactate pyruvate (TALP) supplemented with $6 \mathrm{mg} \mathrm{BSA} \mathrm{m}^{-1}$ ) and fertilized in fertTALP containing $10.0 \mu \mathrm{mol}$ hypotaurin $\mathrm{I}^{-1}$ (Sigma), $1.0 \mu \mathrm{mol}$ adrenaline $\mathrm{I}^{-1}$ (Sigma), 0.1 iu heparin $\mathrm{I}^{-1}$ (Serva)

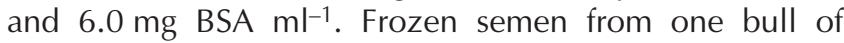
proven fertility in IVF was used. For IVF, semen was prepared by a modified 'swim-up' procedure (Parrish et al., $1986,1988)$. Briefly, semen was thawed in a waterbath at $37^{\circ} \mathrm{C}$ for $1 \mathrm{~min}$. After swim-up separation for $1 \mathrm{~h}$ in spermTALP containing $6 \mathrm{mg} \mathrm{BSA} \mathrm{ml}^{-1}$, the semen was washed twice by centrifugation (at $350 \mathrm{~g}$ at $36^{\circ} \mathrm{C}$ for $10 \mathrm{~min}$ ) before being resuspended in fert-TALP supplemented with $10.0 \mu \mathrm{mol}$ hypotaurin $\mathrm{I}^{-1}$ (Sigma), $1.0 \mu \mathrm{mol}$ adrenaline $\mathrm{I}^{-1}$ (Sigma) and 0.1 iu heparin $\mathrm{I}^{-1}$ (Serva), and BSA. The final concentration of spermatozoa added to each fertilization drop was $1 \times 10^{6}$ spermatozoa $\mathrm{ml}^{-1}$. Fertilization occurred during a $19 \mathrm{~h}$ coincubation period using the same temperature and gas conditions as described for maturation. For in vitro culture in TCM-199, presumptive zygotes were transferred into $200 \mu \mathrm{l}$ drops of TCM-199 supplemented with $10 \%$ oestrous cow serum and were then cultured for up to 9 days under the same conditions as described above, to produce a complete developmental series from zygotes to hatched blastocysts. For culture in the synthetic oviduct serum system, fertilized oocytes (18-19 h after insemination) were denuded from the cumulus cells by vortexing for 3 min in TCM-air followed by gentle pipetting, and were then transferred in groups of six to eight oocytes (after washing three times in culture medium) into $30 \mu \mathrm{l}$ drops of synthetic oviduct fluid (Tervit et al., 1972) containing $0.33 \mathrm{mmol}$ pyruvate $\mathrm{I}^{-1}, 50.0 \mu \mathrm{g}$ gentamicin $\mathrm{ml}^{-1}, 10.0 \mu \mathrm{g}$ phenol red $\mathrm{ml}^{-1}, 1 \mathrm{ml}$ per $100 \mathrm{ml}$ essential amino acids of basal Eagle medium (Sigma), $2 \mathrm{ml}$ per $100 \mathrm{ml}$ non-essential amino acids of minimum essential medium (Sigma) and $6 \mathrm{mg}$ polyvinyl alcohol $\mathrm{ml}^{-1}$ (Keskintepe and Brackett 1996; Eckert et al., 1998). Embryos were cultured under silicone oil in $5 \% \mathrm{CO}_{2}, 7 \% \mathrm{O}_{2}$ and $88 \% \mathrm{~N}_{2}$ (Air Product, Hattingen) in a humidified atmosphere in modular incubator chambers (ICN Biomedicals, Inc., Aurora, No. 615300, OH) at $39^{\circ} \mathrm{C}$.

The cumulus cells were removed from immature and in vitro matured oocytes as described above. All oocytes or embryos were washed extensively and the absence of 
Table 1. Primers used for PCR

\begin{tabular}{|c|c|c|c|}
\hline $\begin{array}{l}\text { Genes and sequence } \\
\text { references } \\
\text { (EMBL accession no.) }\end{array}$ & Primer sequences and positions & $\begin{array}{c}\text { Annealing } \\
\left({ }^{\circ} \mathrm{C}\right)\end{array}$ & $\begin{array}{l}\text { Fragment size } \\
\text { (base pair) }\end{array}$ \\
\hline $\begin{array}{l}\text { Globin } \\
\text { Cheng et al. (1986) } \\
\text { (X04751) }\end{array}$ & $\begin{array}{l}\text { GCAGCCACGGTGGCGAGTAT }(241-260) \\
\text { GTGGGACAGGAGCTTGAAAT }(555-657)\end{array}$ & 60 & 257 \\
\hline $\begin{array}{l}\text { IGF-I } \\
\text { Fotsis et al. (1990) } \\
\text { (X15726) }\end{array}$ & $\begin{array}{l}\text { GATGGGCATTTCCCCCAATGAA-ATAAGTAA (580-609) } \\
\text { CTGTAAAACAAACAGCCTGTGT-TGCGTAGA (884-913) }\end{array}$ & 55 & 334 \\
\hline $\begin{array}{l}\text { IGF-IR } \\
\text { Sneyers et al. (1991) } \\
\text { (X54980) }\end{array}$ & $\begin{array}{l}\text { CATCTCCAACCTCCGGCCTTTT-АСTCT (186-213) } \\
\text { CССАGССТGСTGCTATTTCTTTT-TCTAT (695-722) }\end{array}$ & 59 & 538 \\
\hline $\begin{array}{l}\text { IGF-II } \\
\text { Brown et al. (1990) } \\
(\text { X53553) }\end{array}$ & $\begin{array}{l}\text { CTTCAGCCGACCATCCAGCCGC-ATAAAC (67-96) } \\
\text { TCAGCGGACGGTGACTCTTGGC-СTCTCT (362-389) }\end{array}$ & 64 & 323 \\
\hline $\begin{array}{l}\text { IGF-IIR } \\
\text { Lobel et al. }(1987,1988) \\
\text { (J03527 and M15869) }\end{array}$ & $\begin{array}{l}\text { CGCCTACAGCGAGAAGGGGTTA-GTC (4799-4823) } \\
\text { AGAAAAGCGTGCACGTGCGCTT-GTC (5067-5091) }\end{array}$ & 62 & 393 \\
\hline
\end{tabular}

IGF: insulin-like growth factors; IGF-R: insulin-like growth factor receptors.

cumulus cells was verified at $\times 200$ magnification to ensure that the transcripts did not originate from residual cumulus cells. Pools of immature and matured oocytes, zygotes, two- to four-cell embryos, 8-16-cell embryos, morulae, expanded blastocysts and hatched blastocysts were collected at the appropriate stages of development. Oocytes or embryos that had not reached the expected developmental stage at the respective time points in both treatment groups were discarded from this study. Presumptive matured oocytes or zygotes were examined under a phase-contrast microscope at $\times 400$ for the presence of the first polar body or two pronuclei. All embryos at all stages of development were examined carefully for uniform size and quality. Representative cell counts in subgroups of embryos produced in these systems revealed an average of 50-60 cells in morulae and 110-120 cells in blastocysts (Wrenzycki et al., 2001). After washing three times in PBS containing $0.1 \%$ polyvinyl alcohol, embryos were stored in pools of $20-25$ at $-80^{\circ} \mathrm{C}$ in a minimum volume ( $5 \mu$ l or less) of medium until use.

\section{Isolation of RNA}

Poly(A)+ RNA was isolated using a Dynabeads mRNA DIRECT Kit (Dynal, Oslo) according to the manufacturer's instructions, with minor modifications (Wrenzycki et al., 1999). Briefly, oocytes or embryos were lysed by the addition of $150 \mu \mathrm{l}$ lysis/binding buffer $(100 \mathrm{mmol}$ Tris- $\mathrm{HCl}$ $\mathrm{I}^{-1}, \mathrm{pH} 8.0,500 \mathrm{mmol} \mathrm{LiCl} \mathrm{I-1}^{-1}, 10 \mathrm{mmol}$ EDTA I-1, 1\% LiDS (SDS) and $5 \mathrm{mmol}^{\mathrm{DDT}} \mathrm{I}^{-1}$ ). Subsequently, $0.1 \mathrm{pg}$ rabbit globin mRNA (BRL, Gaithersburg, MD) per oocyte or embryo was added to each tube as an internal standard. After vortexing for $10 \mathrm{~s}$, brief centrifugation (12 $000 \mathrm{~g}, 15 \mathrm{~s}$ ) and incubation at room temperature for $10 \mathrm{~min}, 10 \mu \mathrm{l}$ prewashed Dynabeads oligo $(\mathrm{dT})_{25}$ was pipetted into the fluid. After incubation of poly $(\mathrm{A})^{+}$RNAs with oligo(dT) Dynabead at room temperature for $5 \mathrm{~min}$, the beads were separated using a Dynal MPC-E-1 magnetic separator, washed once using $100 \mu \mathrm{l}$ washing buffer 1 (10 mmol

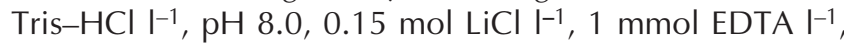
$0.1 \%$ LiDS) and then washed three times with $100 \mu \mathrm{l}$ washing buffer 2 (10.0 mmol Tris- $\mathrm{HCl} \mathrm{I}^{-1}, \mathrm{pH} 8.0,0.15 \mathrm{~mol}$

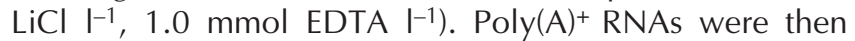
eluted from the beads by incubation in $11 \mu \mathrm{l}$ sterile water at $65^{\circ} \mathrm{C}$ for $2 \mathrm{~min}$, and aliquots were used immediately for reverse transcription (RT). As a positive control, total RNA was also extracted from bovine oviduct tissue (Chomczynski and Sacchi, 1987) with minor modification as described by Wrenzycki et al. (1998).

\section{Reverse transcription}

Poly $(A)+$ RNA isolated from different numbers of oocytes or embryos (20-25), or total RNA from oviductal tissue, was reverse transcribed into cDNA in a total volume of $20 \mu \mathrm{l}$ using $2.5 \mu \mathrm{mol}$ random hexamers (Perkin-Elmer, Vaterstetten) to obtain the widest range of cDNA. The reaction mixture consisted of $1 \times \mathrm{RT}$ buffer $(50 \mathrm{mmol} \mathrm{KCl}$ $\mathrm{I}^{-1}, 10 \mathrm{mmol}$ Tris- $\mathrm{HCl} \mathrm{I}^{-1}, \mathrm{pH} 8.3$, Perkin-Elmer), $5 \mathrm{mmol}$ $\mathrm{MgCl}_{2} \mathrm{I}^{-1}, 1 \mathrm{mmol}$ of each dNTP I-1(Amersham, Brunswick), 20 iu Rnase inhibitor (Perkin-Elmer) and 50 iu MuLV reverse 
transcriptase (Perkin-Elmer). The $\mathrm{RT}$ reaction was carried out at $25^{\circ} \mathrm{C}$ for $10 \mathrm{~min}$ and at $42^{\circ} \mathrm{C}$ for $1 \mathrm{~h}$ followed by a denaturation step at $99^{\circ} \mathrm{C}$ for $5 \mathrm{~min}$, and flash cooling on ice. The reaction mixture was diluted to get a final concentration of 0.5 oocyte or embryo equivalent per $\mu \mathrm{l}$, and 50 fg globin RNA $\mu \mathrm{I}^{-1}$.

\section{Polymerase chain reaction}

PCR was performed with cDNA equivalents corresponding to four oocytes or embryos (IGF-II: eight embryo equivalents) from different pools of oocytes or embryos generated in different in vitro produced runs, and $100 \mathrm{fg}$ of globin RNA in a final volume of $50 \mu$ of $1 \times$ PCR buffer $(20$ mmol Tris- $\mathrm{HCl} \mathrm{I-1}$, $\mathrm{pH} 8.4,50 \mathrm{mmol} \mathrm{KCl} \mathrm{I-1}^{-1}$ Gibco BRL, Eggenstein), $1.5 \mathrm{mmol} \mathrm{MgCl}_{2} \mathrm{I}^{-1}, 200 \mu \mathrm{mol}$ of each dNTP $\mathrm{I}^{-1}, 0.5 \mu \mathrm{mol}$ of each sequence-specific primer $\mathrm{I}^{-1}$ (except for IGF-II primer which was used at a concentration of 1.0 $\mu \mathrm{mol} \mathrm{I}^{-1}$ ) using a PTC-200 thermocycler (MJ Research, Watertown, MA). A 'hot start' was used by adding 1 iu Taq DNA polymerase (Gibco) at $72^{\circ} \mathrm{C}$ to ensure specific amplification. PCR primers were designed from the coding regions of each gene sequence using the OLIGO program. The sequence and positions of the primers used, the annealing temperatures, the fragment sizes and the sequence reference of the expected PCR products are summarized (Table 1).

The PCR program used an initial step of $97^{\circ} \mathrm{C}$ for 2 min and $72^{\circ} \mathrm{C}$ for 2 min (hot start) followed by 35 cycles (globin: 27 cycles and IGF-II: 37 cycles) of $15 \mathrm{~s}$ each at $95^{\circ} \mathrm{C}$ for DNA denaturation, $15 \mathrm{~s}$ at different temperatures for annealing of the primers, and $15 \mathrm{~s}$ at $72^{\circ} \mathrm{C}$ for primer extension. The last cycle was followed by an additional $5 \mathrm{~min}$ at $72^{\circ} \mathrm{C}$ and then a cooling period to $4^{\circ} \mathrm{C}$. The products from each primer pair were sequenced to confirm the identity of the RT-PCR fragments. As negative controls, tubes were always prepared in which RNA or reverse transcriptase was omitted during the RT-reaction. Poly(A)-polymerase proved to be a good positive control for the presence of embryonic RNA as these transcripts were detectable in all preimplantation stages. Generation of the diagnostic fragments was strictly dependent on the presence of RNA in the RT reaction, as omission of reverse transcriptase from the RT did not generate any amplified fragments (data not shown).

After the addition of $5 \mu$ of $10 \times$ loading buffer $(0.25 \%$ (w/v) xylenecyanol and $25 \mathrm{mmol}^{\mathrm{EDTA} \mathrm{I}} \mathrm{I}^{-1}$ in $50 \%$ glycerin), the RT-PCR products were subjected to electrophoresis on a $1.5 \%$ agarose gel in I $\times$ TBE buffer $\left(90 \mathrm{mmol}^{\text {Tris } \mathrm{I}^{-1}, 90 \mathrm{mmol}}\right.$ borate $\mathrm{I}^{-1}, 2$ mmol EDTA $\mathrm{I}^{-1}, \mathrm{pH}$ 8.3) containing $0.2 \mathrm{pg} \mathrm{EtBr}$ $\mathrm{ml}^{-1}$ with further addition of $\mathrm{EtBr}$ in the same concentration as the running buffer. After they were run at $80 \mathrm{~V}$ for $45 \mathrm{~min}$, the fragments were visualized on a $312 \mathrm{~nm}$ UV-transilluminator. The image of each gel was recorded using a CCD camera (Quantix, Photometrics, München) and the IP Lab Spectrum program (Signal Analytics Corporation, Vienna, VA). The intensity of each band was determined by densitometry using an image analysis program (IPLab Gel). The relative amount of the mRNA of interest was calculated by dividing the intensity of the band for each developmental stage by the intensity of the globin band for the corresponding stage. Experiments were repeated for each mRNA, with a minimum of four or five separate oocyte or embryo batches each derived from different in vitro produced runs.

For each pair of gene-specific primers, semilog plots of the fragment intensity as a function of cycle number were used to determine the range of numbers of cycles over which linear amplification occurred, and the number of PCR cycles was kept within this range. For the growth factor genes and their receptors, a linear range was observed from 31 to 39 amplification cycles (data not shown). These preliminary amplification experiments were performed with a fixed amount of RNA. The fixed number of cycles was used to demonstrate that the amount of RNA added gave a proportional output of RT-PCR product (data not shown). Because the total efficiency of amplification for each set of primers during each cycle is not known, these assays can be used only to compare relative abundances of a specific mRNA among different samples (Temeles et al., 1994). The recovery rate of RNA was estimated as the ratio between the intensity of the globin band with and without the RNA preparation procedure, starting with an equivalent of $50 \mathrm{fg}$ in the PCR reaction. On average, $66 \%$ of poly $(\mathrm{A})$-tailed RNA was recovered using our Dynabead oligo $d(T) m R N A$ isolation method, which is in agreement with published yields (Shim et al., 1996). After optimization, the RT-PCR assay was sensitive enough to detect specific bovine mRNA from bovine oviduct at concentrations from 0.5 to $5.0 \mathrm{ng}$ of total RNA (a blastocyst contains approximately $10 \mathrm{ng}$ of total RNA) (data not shown). Pools of embryos were used to minimize the effect of individual variation of oocytes or embryos (DeSousa et al., 1998). Krüssel et al. (1998) have shown that mRNA patterns differ markedly even among single blastomeres from the same embryo.

\section{Statistical analysis}

Data were analysed using the SigmaStat 2.3 (Jandel Scientific, San Rafael, CA) software package. After testing for normality (Kolmogorov-Smirnov test with Lilliefor correction) and equal variance (Levene Median test), a oneway ANOVA (or a one-way ANOVA on ranks) followed by multiple pairwise comparisons using either Tukey's test or Duncan's method was used to determine differences between both treatments at the same developmental stage and in the temporal expression patterns within one treatment group. Differences were considered to be significant at $P \leqslant 0.05$.

\section{Results}

\section{Development in vitro}

The developmental rates of bovine embryos generated in the TCM system or synthetic oviduct fluid system are summarized (Table 2). A significantly higher percentage of 
Table 2. Culture efficiency (mean \pm SEM) of bovine embryos produced in vitro

\begin{tabular}{lcr}
\hline & \multicolumn{2}{c}{$\begin{array}{c}\text { Percentage of embryos } \\
\text { (relative to absolute number of oocytes) }\end{array}$} \\
\cline { 2 - 3 } Stage of development & TCM-199 + ECS & SOF + PVA \\
\hline 2-4-cell embryo (day 2) & $60.7 \pm 1.0^{\mathrm{a}}$ & $54.8 \pm 1.8^{\mathrm{b}}$ \\
& $(281 / 468)$ & $(447 / 828)$ \\
8-16-cell embryo (days 3-4) & $47.0 \pm 1.7$ & $46.8 \pm 2.3$ \\
& $(167 / 371)$ & $(236 / 514)$ \\
Morulae (day 6) & $33.1 \pm 0.7$ & $(198 / 523)$ \\
& $(135 / 410)$ & $16.5 \pm 0.6^{\mathrm{b}}$ \\
Expanded blastocysts (days 8-9) & $25.0 \pm 1.2^{\mathrm{a}}$ & $(174 / 1061)$ \\
\hline
\end{tabular}

abValues with different superscripts within one stage of development are significantly different $(P \leqslant 0.05)$.

ECS: oestrous cow serum; SOF: synthetic oviduct fluid; PVA: polyvinyl alcohol.

two- to four-cell embryos and blastocysts was obtained in the TCM system than in the synthetic oviduct fluid system. Embryos cultured in the presence of serum appeared darker and had more 'granules' than those cultured in the serumfree system.

\section{Ontogenetic expression pattern of IGFS}

Representative gel photos of mRNA expression in bovine hatched blastocysts cultured in the TCM system or synthetic oviduct fluid system are shown (Fig. 1). IGF-I transcripts were not detected at any stage of preimplantation bovine development even when PCR was performed with cDNA equivalents corresponding to $>16$ oocytes or embryos (Fig. 2). Matured oocytes generally had more mRNA for IGF-IR, IGF-II and IGF-IIR than did immature oocytes (except for IGF-IR oocytes in the TCM system). At maturation, mRNA expression of IGFs and their receptors decreased significantly during early development until activation of the embryonic genome at the 8-16-cell stage, when an increase was observed. There was a significant increase in mRNA expression of IGFs and their receptors at the hatched blastocyst stage.

\section{Effects of medium conditions}

The relative abundances of IGF-IR, IGF-II and IGF-IIR gene transcripts found in the two culture systems are summarized (Fig. 3). In the TCM system, IGF-IR was expressed in the immature oocyte up to the two- to four-cell embryo stage. Expression of IGF-IR decreased up to the morula stage and then increased up to the hatched blastocyst stage. In the synthetic oviduct fluid system, a similar pattern of expression for IGF-IR was observed. There was a decrease in IGF-IR mRNA up to the maternalembryonic transition at the 8-16-cell stage followed by an increase during further embryonic development up to the blastocyst stage. The amount of IGF-IR mRNA was consistently lower in embryos cultured in the synthetic oviduct fluid system than in those cultured in the TCM system. The individual differences in IGF-IR, IGF-II and IGFIIR gene expression of embryos generated in the two media were not significant except at the expanded blastocyst stage when IGF-IIR transcripts were significantly higher in the TCM system than in the synthetic oviduct fluid system.

\section{Discussion}

This study is the first to report on changes in the relative abundance of mRNAs for IGF-I, IGF-II and their receptors throughout bovine preimplantation development in vitro. Bovine embryos were cultured in two different culture systems and a semi-quantitative RT-PCR assay was used with the addition of exogenous globin as internal standard (Wrenzycki et al., 1999). Changes in mRNA expression in the two different culture systems (a TCM system and a synthetic oviduct fluid system) were detected, providing additional information to the findings reported by Wrenzycki et al. $(1999,2001)$ on the effect of culture conditions on mRNA expression. However, it is not possible to use the semi-quantitative RT-PCR assay to differentiate between an increase in transcription, an increase in RNA stability or a change in the poly $(\mathrm{A})$ tail length (Wrenzycki et al., 1999).

The concentrations of mRNA for IGF-II, IGF-IIR and IGFIR seem to follow a pattern similar to most genes expressed during oocyte maturation in that they increased, indicating that maturation may depend on increased mRNA from these genes. After maturation, IGF concentrations decreased gradually, as expected, up to maternal-embryonic transition at the 8-16-cell stage. After the maternal-embryonic transition, concentrations of IGF-II, IGF-IIR and IGF-IR mRNA increased up to the hatched blastocyst stage. In human embryos, the relative abundance of mRNAs for IGFs and their receptors increases from the three- to four-cell stage (for example, after maternal-embryonic transition) up to the blastocyst stage (Liu et al., 1997). In the present study 


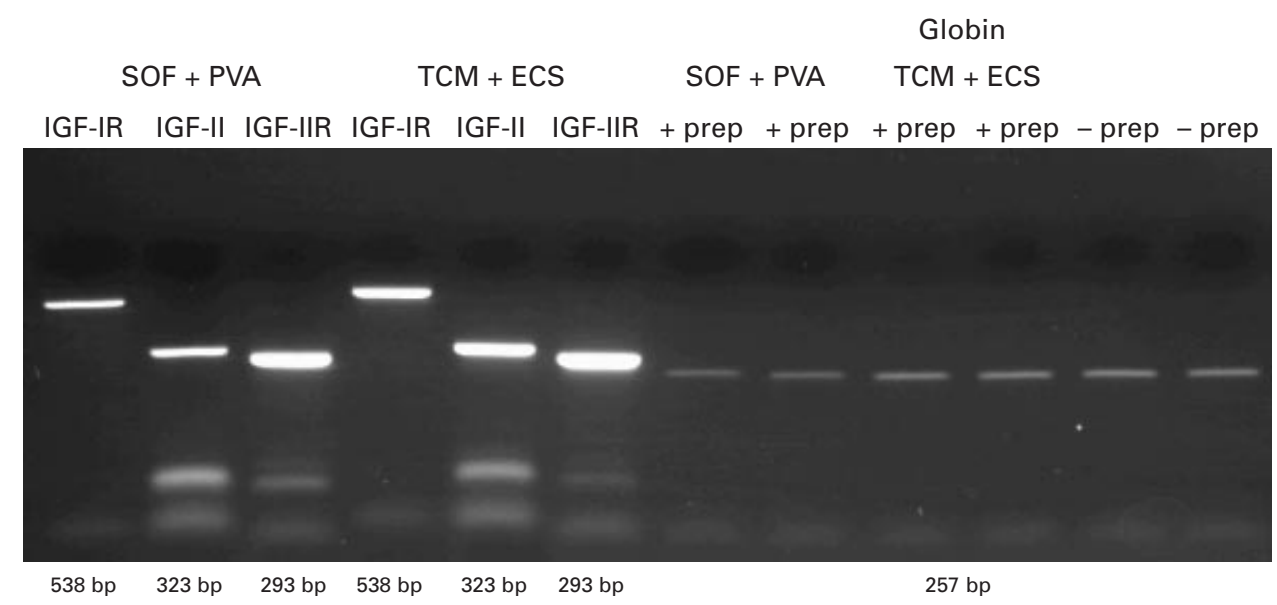

Fig. 1. Semi-quantitative RT-PCR analysis of mRNA insulin-like growth factor I receptor (IGF-IR), IGF-II and IGF-IIR in bovine hatched blastocysts produced in vitro. Each lane represents the RT-PCR product derived from poly $(\mathrm{A})^{+} \mathrm{RNA}$ from the equivalent of four embryos (IGF-II: eight embryos). The RNA recovery rate was estimated as the ratio between the intensity of the fragment with (globin +prep) and without preparation (-prep). SOF: synthetic oviduct fluid; PVA: polyvinyl alcohol; ECS: oestrous cow serum; bp: base pairs.

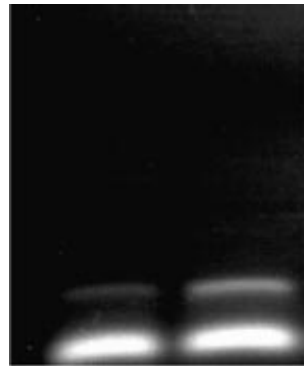

1 2

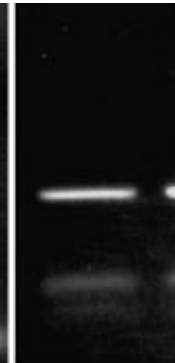

3

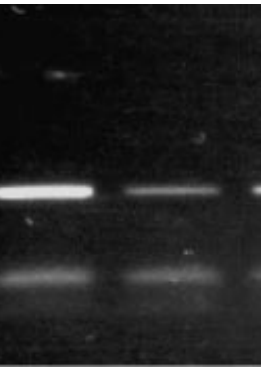

4 5

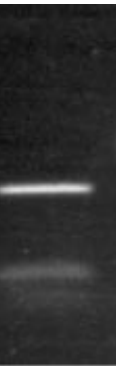

6

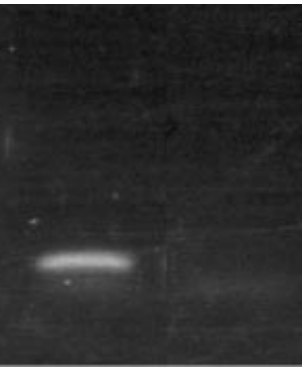

7

8

Fig. 2. Detection of insulin-like growth factor I (IGF-I) transcripts in mRNA from bovine expanded blastocysts and RNA from bovine oviduct and uterus. Lane 1: eight expanded blastocysts; lane 2: 16 expanded blastocysts; lane 3: 20 ng oviduct-RNA; lane 4: 40 ng oviduct-RNA; lane 5: 20 ng uterusRNA; lane 6: 40 ng uterus-RNA; lane 7: negative control without RT; and lane 8: negative control without RNA. Arrow indicates expected size of the fragment in base pairs.

on bovine embryos, the greatest increase in IGF mRNA occurred after hatching. The increase in IGF-IR, IGF-II and IGF-IIR mRNA observed as the bovine embryo reached the hatched blastocyst stage may indicate an important role for growth factors of the IGF family as the bovine embryo becomes filamentous in shape. Blondin et al. (2000) reported that the extended in vitro culture period used to generate viable bovine blastocysts from immature oocytes led to significant alterations in IGF-II mRNA steady state concentrations in the liver and skeletal muscle of fetuses at day 70 of gestation. This finding indicates that further studies into the role of IGFs in 'large offspring syndrome', which is frequently observed in calves derived from certain in vitro production systems (Niemann and Wrenzycki, 2000), might be valuable.

In contrast to other reports in which IGF-I mRNA was found in preimplantation bovine and mouse embryos (Schultz et al., 1992; Watson et al., 1992; Doherty et al., 1994, Yoshida et al., 1998; Lonergan et al., 2000), in the present study, mRNA for IGF-I was not detected in embryos derived from the two culture systems. This finding is consistent with observations in preimplantation embryos of mice (Rappolee et al., 1992), rats (Zhang et al., 1994), water buffalo (Daliri et al., 1999) and humans (Lighten et al., 1997a), in which IGF-I mRNA was not detected. Lonergan et al. (2000) used nested PCR to identify IGF-I transcripts in early bovine embryos. Furthermore, bovine embryos produced in vitro did not release IGF-I protein, although large amounts of IGF-II were observed (Winger et al., 1997). The conflicting results with regard to IGF-I expression in bovine embryos may be due to differences in culture systems or interaction of RT-PCR with specific components used in the experiments, 

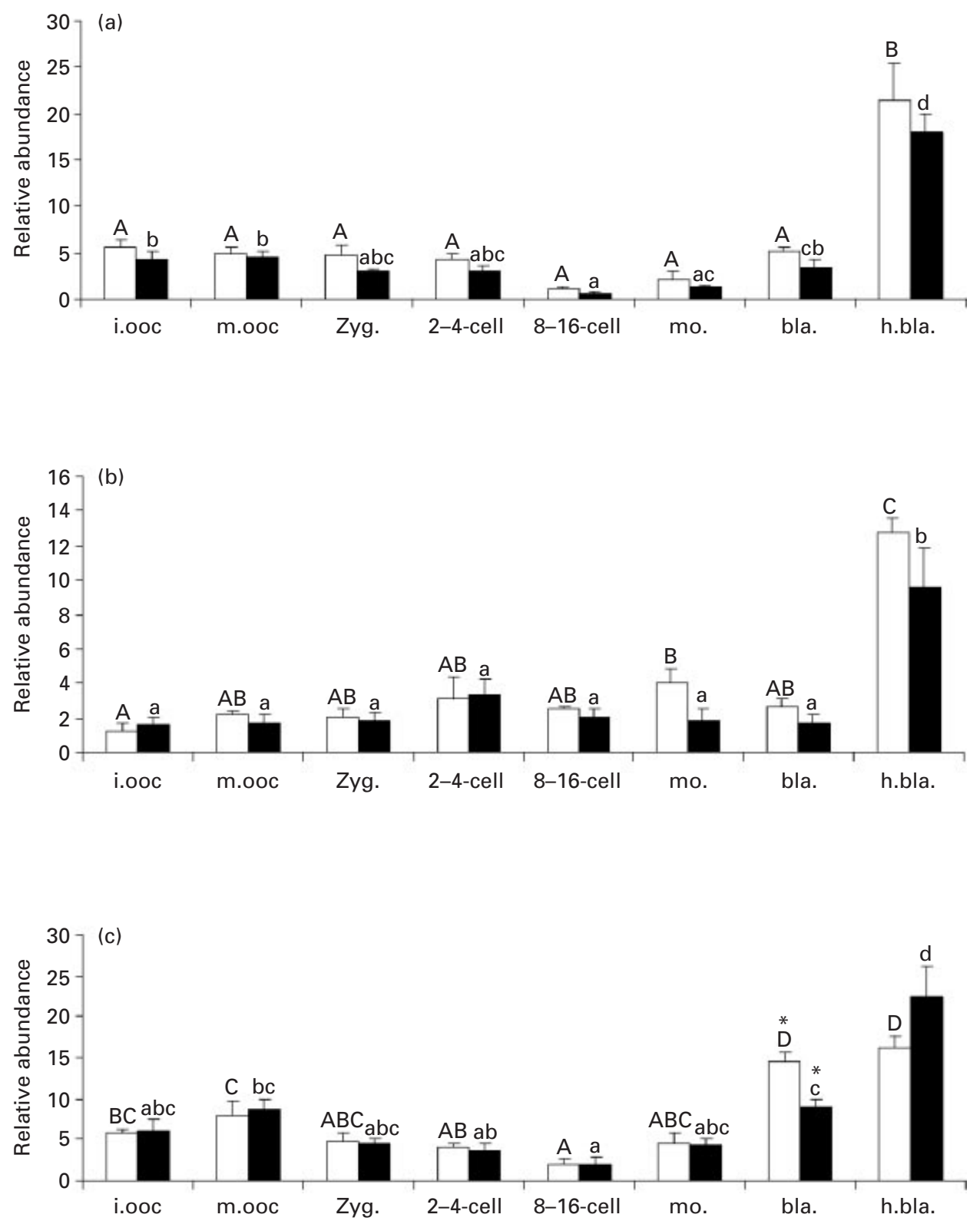

Fig. 3. Relative abundance of (a) insulin-like growth factor I receptor (IGF-IR), (b) IGF-II and (c) IGFIIR gene transcripts (mean \pm SEM) throughout bovine preimplantation development (i.ooc: immature oocyte; m.ooc: matured oocyte; Zyg.: zygote; 2-4-cell: 2-4-cell embryo; 8-16-cell: 8-16-cell embryo; mo.: morula; bla.: blastocyst; h.bla.: hatched blastocyst) using TCM-oestrous cow serum (ECS) $(\square)$ or synthetic oviduct fluid (SOF)-polyvinyl alcohol (PVA) (ם) as culture systems. Significant differences throughout preimplantation development are indicated by different letters (TCM-ECS: A, B,C,D $=P<0.05$; SOF-PVA a,b,c,d $=P<0.05$ ), whereas values with the same symbol $(*)$ indicate significant differences $(P<0.05)$ between embryos at the same development stage in the two culture systems.

particularly the design of primer pairs. Results from the present study indicate that the paracrine rather than the autocrine mechanism is favoured as the mode of action for IGF-I. Embryonic expression of IGF-I most likely does not begin until after implantation. In contrast to mRNA for IGF-I, mRNA for IGF-IR, IGF-II and IGF-IIR was detected at all stages of preimplantation bovine development, which is consistent with previous observations (Rappolee et al., 1992; Watson et al., 1992; Yoshida et al., 1998, Lonergan et al., 2000). Autocrine and paracrine IGF-II activity appear to be important as IGF-II mRNA is present in preimplantation embryos and in the reproductive tract (Buhi et al., 1997). In 
other studies, autocrine and paracrine mechanisms for IGF-II and TGF $\alpha$ action have been suggested (Eicher et al., 1993; Zhang et al., 1994).

Alterations in mRNA expression can be associated with differences in the culture environment (Wrenzycki et al., 1999, 2001). The timing and magnitude of these alterations vary among the different transcripts and are significantly affected by the presence of exogenous protein in a stagespecific manner, predominantly at critical developmental time points. In the present study, the amounts of IGF-IR mRNA were slightly higher at all stages of development in embryos derived and cultured in the TCM system than in embryos that had been cultured in the synthetic oviduct fluid system. Although individual stage-specific concentrations were not significantly different, concentrations of IGF-IR were consistently lower in the synthetic oviduct fluid system. The similarity of the patterns (an increase during oocyte maturation, a decrease up to maternal-embryonic transition and an increase after maternal-embryonic transition) of growth factor gene expression in the two media indicates an important role of growth factors in preimplantation development.

The presence of transcripts for IGF-IR, IGF-II and IGF-IIR in all preimplantation bovine embryos from the immature oocyte to the hatched blastocyst stage indicates that maternal transcripts occur in the oocyte and that these transcripts persist at cleavage stages before activation of the embryonic genome. IGF-II mediates growth in early mouse embryos and forms a pathway in which imprinted genes affect development during preimplantation stages (Rappolee et al., 1992). The IGF-II ligand is imprinted when inherited maternally and IGF-IIR is imprinted when inherited paternally (De-Chiara et al., 1990; Barlow et al., 1991; Latham et al., 1994), consistent with the hypothesis of Haig and Graham (1991) which predicts that imprinting of growth factors such as IGF-II, IGF-IIR and IGF-IR regulates embryonic growth in the mammalian uterus. Lighten et al. (1997b) suggested that IGF-II is parentally imprinted in human preimplantation embryos. However, there is little information available with regard to imprinting of these genes in cattle.

Wrenzycki et al. (2001) showed that embryos generated in the synthetic oviduct fluid system appear to be more similar to their in vivo counterparts with regard to gene expression patterns than those generated in the TCM system. This similarity may also be attributed to the reduced oxygen tension of the synthetic oviduct fluid system via the reduction of deleterious effects of reactive oxygen species on early development (Johnson and Nasr-Esfahani, 1994). In the present study, the abundance of IGF-IR, IGF-II and IGF-IIR transcripts in preimplantation bovine embryos generated in the TCM system was greater than it was in the synthetic oviduct fluid system. From these results, it is possible to speculate that IGFs play a role as survival factors in preimplantation bovine embryos. IGF-I has been shown to prevent apoptosis in early rabbit embryos and to act as a survival factor (Herrler et al., 1998). These findings indicate a potentially more versatile role of IGFs in preimplantation development than previously suggested.

Determination of growth factor gene expression in preimplantation bovine development can be used for optimization of in vitro culture systems, with the goal of improving the quality of embryos generated in vitro and ensuring normal offspring. Further studies are underway to investigate growth factor gene expression in embryos produced in vivo in an effort to clarify the effects of culture conditions.

The authors are grateful to E. Lemme and K. Korsawe for their skilled technical assistance. Gratitude is expressed to W. Kues and A. Lucas-Hahn for their helpful discussion. M. Yaseen has been supported by a fellowship from the Egyptian Government. The financial support from the EU (FAIR CT 98-4339) is gratefully acknowledged.

\section{References}

Adashi EY, Resnick CE, D'Ercole J, Svoboda ME and Van Wyck JJ (1985) Insulin-like growth factors as intraovarian regulators of granulosa cells Endocrinology Reviews 6 400-420

Barlow DP, Stoger R, Hermann BG, Saito K and Schweifer N (1991) The mouse insulin-like growth factor Nature 349 84-87

Baxter RC (1988) The insulin-like growth factors and their binding proteins Comparative Biochemistry and Physiology 91 229-235

Blondin P, Farin RW, Crosier AE, Alexander JE and Farin CE (2000) In vitro production of embryos alters levels of insulin-like growth factor-II messenger ribonucleic acid in bovine fetuses 63 days after transfer Biology of Reproduction 62 384-389

Brown WM, Dziegielewska KM, Foreman RC and Saunders NR (1990) The nucleotide and deduced amino acid sequences of insulin-like growth factor II cDNAs from adult bovine and sheep liver Nucleic Acid Research 184614

Buhi WC, Alvarez JM and Kouba AJ (1997) Oviductal regulation of fertilization and early embryonic development Journal of Reproduction and Fertility Supplement 52 285-300

Cheng J-F, Raid L and Hardison RC (1986) Isolation and nucleotide sequence of rabbit globin gene cluster $\Psi \zeta-\alpha 1 \Psi \alpha$ : absence of a pair of $\alpha-$ globin genes evolving in concert Journal of Biology and Chemistry 261 839-848

Chomczynski P and Sacchi N (1987) Single-step method of RNA isolation by acid guanidinium thiocyanate-phenol-chloroform extraction Analytical Biochemistry 162 156-159

Daliri M, Appa Rao KBC, Kaur G, Garg S, Patil S and Totey SM (1999) Expression of growth factor ligand and receptor genes in preimplantation stage water buffalo (Bubalus bubalis) embryos and oviduct epithelial cells Journal of Reproduction and Fertility 117 61-70

De-Chiara TM, Efstratiadis A and Ropertson El (1990) A growth-deficiency phenotype in heterozygous mice carrying an insulin-like growth factor II gene disrupted by targeting Nature 345 78-80

DeSousa PA, Westhusin ME and Watson AJ (1998) Analysis of variation in relative mRNA abundance of specific gene transcripts in single bovine oocytes and early embryos Molecular Reproduction and Development 49 119-130

Doherty AS, Temeles GL and Schultz RM (1994) Temporal pattern of IGF-I expression during mouse preimplantation embryogenesis Molecular Reproduction and Development 37 21-26

Eckert J and Niemann $\mathbf{H}$ (1995) In vitro maturation, fertilization and culture to blastocysts of bovine oocyte in protein-free media Theriogenology 43 1211-1225

Eckert J, Pugh PA, Thompson JG, Niemann H and Tervit HR (1998) Exogenous protein affects developmental competence and metabolic activity of bovine pre-implantation embryos in vitro. Reproduction, Fertility and Development 10 327-332 
Eicher DJ, Moats-Staats BM, Stiles AD and D'Ercole AJ (1993) Possible autocrine/paracrine actions of insulin-like growth factors during embryonic development: expression and action of IGFs in undifferentiated P19 cells Development and Genetics 14 194-203

Fotsis T, Murphy C and Gannon F (1990) Nucleotide sequence of the bovine insulin-like growth factor 1 (IGF-1) and ist IGF-1A precursor Nucleic Acid Research 18676

Haig D and Graham C (1991) Genomic imprinting and the strange case of the insulin-like growth factor receptor Cell 64 1045-1046

Hammond JM, Hsu CJ, Klindt J, Tsang BK and Downey BR (1988) Gonadotropins increase concentrations of immunoreactive insulin-like growth factor-I in porcine follicular fluid in vivo. Biology of Reproduction 38 304-308

Herrler A, Lucas-Hahn A and Niemann H (1992) Effect of insulin-like growth factor-I on in vitro production of bovine embryos Theriogenology 37 1213-1224

Herrler A, Krusche CA and Beier HM (1998) Insulin and Insulin-like growth factor-I promote rabbit blastocyst development and prevent apoptosis Biology of Reproduction 59 1302-1310

Heyner S, Shi C, Garside WT and Smith RM (1993) Functions of the IGFs in early mammalian development Molecular Reproduction and Development 35 421-426

Johnson MH and Nasr-Esfahani MH (1994) Radical solutions for culture problems: could free oxygen radicals be responsible for the impaired development of preimplantation mammalian embryos in vitro? Bioassays 16 31-38

Kamada S, Kubota T, Taguchi M, Ho WR, Sakamoto S and Aso T (1992) Effect of insulin-like growth factor-II on proliferation and differentiation of ovarian granulosa cells Hormone Research 37 141-149

Kaye PL and Harvey MB (1995) The role of growth factors in preimplantation development Progress in Growth Research 6 1-24

Kaye PL, Bell KL, Beebe FS, Dunglison GF, Gardner HG and Harvey MB (1992) Insulin and the insulin-like growth factors (IGFs) in preimplantation development Reproduction, Fertility and Development $473-86$

Keskintepe L and Brackett BG (1996) In vitro development competence of in vitro-matured bovine oocytes fertilized and cultured in completely defined media Biology of Reproduction 55 333-339

Krüssel JS, Huang HY, Simon C, Behr B, Pape AR, Wen Y, Bielfeld P and Polan ML (1998) Single blastomeres within human preimplantation embryos express different amounts of messenger ribonucleic acid for beta-actin and interleukin-1 receptors type I Journal of Clinical Endocrinology and Metabolism 83 953-959

Latham K, Doherty AS, Scott CD and Schultz RM (1994) Igf2r and Igf2 gene expression in androgenetic, gynogenetic and parthenogenetic preimplantation mouse embryos: absence of regulation by genomic imprinting Genes and Development 8 290-299

Lighten AD, Hardy K, Winston RML and Moore GE (1997a) Expression of mRNA for the insulin-like growth factors and their receptors in human preimplantation embryos Molecular Reproduction and Development 47 134-139

Lighten AD, Hardy K, Winston RML and Moore GE (1997b) IGF is parentally imprinted in human preimplantation embryos Nature Genetics 15 122-123

Liu HC, He ZY, Mele CA, Veeck LL, Davis OK and Rosenwaks Z (1997) Expression of IGFs and their receptors is a potential marker for embryo quality American Journal of Reproduction and Immunology 38 237-245

Lobel P, Dahms NM, Breitmeyer J, Chirgwin JM and Kornfeld S (1987) Cloning of the bovine 215-kDa cation-independent mannose 6phosphate receptor Proceedings National Academy of Sciences USA 84 2233-2237

Lobel P, Dahms NM and Kornfeld S (1988) Cloning and sequence analysis of the cation-independent mannose 6-phosphate receptor Journal of Biological Chemistry $2632563-2570$

Lonergan P, Gutierrez-Adan A, Pintado B, Fair T, Ward F, de la Fuente J and Boland M (2000) Relationship between time of first cleavage and the expression of IGF-I growth factor, its receptors, and two housekeeping genes in bovine two-cell embryos and blastocysts produced in vitro. Molecular Reproduction and Development 57 146-152
Luciano AM, Modina S, Gandolfi F, Lauria A and Armstrong DT (2000) Effect of cell-to-cell contact on in vitro deoxyribonucleic acid synthesis and apoptosis of bovine granulosa cells to insulin-like growth factor-I and epidermal growth factor Biology of Reproduction 63 1580-1585

Matsui M, Takahashi Y, Hishinuma M and Kanagawa H (1995) Insulin and insulin-like growth factor-I (IGF-I) stimulate the development of bovine embryos fertilized in vitro. Journal of Veterinary Medicine Science $\mathbf{5 7}$ $1109-1111$

Mihalik J, Rehak P and Koppel J (2000) The influence of insulin on the in vitro development of mouse and bovine embryos Physiology Research 49 347-354

Niemann H and Wrenzycki C (2000) Alterations of expression of developmentally important genes in preimplantation bovine embryos by in vitro culture conditions: implications for subsequent development Theriogenology 53 21-34

Palma GA, Muller M and Brem G (1997) Effect of insulin-like growth factor I (IGF-I) at high concentrations on blastocyst development of bovine embryos produced in vitro. Journal of Reproduction and Fertility $\mathbf{1 1 0}$ 347-353

Parrish JJ, Susko-Parrish JL, Leibfried-Rutledge ML, Critser ES, Eyestone WH and First NL (1986) Bovine in vitro fertilization with frozen-thawed semen Theriogenology 25 591-600

Parrish JJ, Susko-Parrish JL, Winer MA and First NL (1988) Capacitation of bovine sperm by heparin Biology of Reproduction 38 1171-1180

Pavlok A, Lucas-Hahn A and Niemann H (1992) Fertilization and development competence of bovine oocytes derived from different categories of antral follicles Molecular Reproduction and Development 31 63-67

Pawshe CH, Appa Rao KBC and Totey SM (1998) Effect of insulin-like growth factor I and its interaction with gonadotropins on in vitro maturation and embryonic development, cell proliferation and biosynthetic activity of cumulus cells and granulosa cells in buffalo Molecular Reproduction and Development 49 277-285

Rappolee DA, Sturm KS, Behrendtsen O, Schultz GA, Pedersen RA and Werb Z (1992) Insulin-like growth factor II acts through an endogenous growth pathway regulated by imprinting in early mouse embryos Genes and Development 6 939-952

Schultz GA, Hogan A, Watson AJ, Smith RM and Heyner S (1992) Insulin, insulin-like growth factors and glucose transport: temporal patterns of gene expression in early murine and bovine embryos Reproduction, Fertility and Development 4 361-371

Shim C, Kwon HB and Kim K (1996) Differential expression of laminin chain-specific mRNA transcripts during mouse preimplantation embryo development Molecular Reproduction and Development $\mathbf{4 4}$ 44-55

Sneyers M, Kettmann R, Massart S, Renaville R, Burny A and Portetelle D (1991) Cloning and characterization of a cDNA encoding the betasubunit of the bovine insulin-like growth factor-1 receptor DNA Sequence 1 405-406

Temeles GL, Ram PT, Rothstein JL and Schultz RM (1994) Expression patterns of novel genes during mouse preimplantation embryogenesis Molecular Reproduction and Development 37 121-129

Tervit HR, Whittingham DG and Rowson LEA (1972) Successful culture in vitro of sheep and cattle ova Journal of Reproduction and Fertility $\mathbf{3 0}$ 493-497

Watson AJ, Hogan A, Hahnel A, Wiemer E and Schultz GA (1992) Expression of growth factor ligand and receptor genes in the preimplantation bovine embryo Molecular Reproduction and Development 31 87-95

Watson AJ, Watson PH, Arcellana-Panlilio M, Warnes D, Walker SK, Schultz GA, Armstrong DT and Seamark RF (1994) A growth factor phenotype map for ovine preimplantation development Biology of Reproduction $\mathbf{5 0} 725-733$

Winger QU, de los Rios P, Han VKM, Armstrong DT, Hill DJ and Watson AJ (1997) Bovine oviductal and embryonic insulin-like growth factor binding proteins: possible regulation of embryotrophic insulin-like growth factor circuits Biology of Reproduction 56 1415-1423

Wrenzycki C, Herrmann D, Carnwath JW and Niemann H (1996) Expression of the gap junction gene connexin43 (Cx43) in preimplantation bovine 
embryos derived in vitro or in vivo. Journal of Reproduction and Fertility $10817-24$

Wrenzycki C, Herrmann D, Carnwath JW and Niemann H (1998) Expression of RNA from developmentally important genes in preimplantation bovine embryos produced in TCM supplemented with bovine serum albumin (BSA) Journal of Reproduction and Fertility 112 387-398

Wrenzycki C, Herrmann D, Carnwath JW and Niemann H (1999) Alterations in the relative abundance of gene transcripts in preimplantation bovine embryos cultured in medium supplemented with either serum or PVA Molecular Reproduction and Development 53 8-18

Wrenzycki C, Herrmann D, Keskintepe L, Martins Jr AP, Sirisathien S, Brackett B and Niemann H (2001) Effects of culture system and protein supplementation on mRNA expression in preimplantation bovine embryos Human Reproduction 16 893-901
Yoshida Y, Miyamura M, Hamano S and Yoshida M (1998) Expression of growth factor ligand and their receptor mRNAs in bovine ova during in vitro maturation and after fertilization in vitro. Journal of Veterinary Medicine Science 60 549-554

Zhang X, Kidder GM, Watson AJ, Schultz GA and Armstrong DT (1994) Possible roles of insulin and insulin-like growth factors in rat preimplantation development: investigation of gene expression by reverse transcription-polymerase chain reaction Journal of Reproduction and Fertility 100 375-380

Received 8 March 2001.

First decision 30 May 2001

Accepted 18 June 2001. 